\title{
How to treat combined respiratory and metabolic acidosis after extracorporeal cardiopulmonary resuscitation?
}

\author{
Xavier Bemtgen ${ }^{1 *} \mathbb{D}$, Florentine Schroth ${ }^{1}$, Tobias Wengenmayer ${ }^{1}$, Paul M. Biever $^{1}$, Daniel Duerschmied ${ }^{1}$, \\ Christoph Benk², Christoph Bode ${ }^{1}$ and Dawid L. Staudacher ${ }^{1}$
}

This comment refers to the article available at https://doi.org/10.1186/cc9976

Keywords: VA-ECMO, eCPR, Survival, Carbon dioxide, $\mathrm{paCO}_{2}, \mathrm{pH}$

Establishing a venoarterial extracorporeal membrane oxygenation (vaECMO) in cardiac arrest is known as extracorporeal cardiopulmonary resuscitation (eCPR). After eCPR, patients commonly present with a combined respiratory and metabolic acidosis [1]. It is clear that acidosis negatively impacts survival after eCPR [2] and that a respiratory acidosis can be easily corrected by vaECMO. Current guidelines for conventional CPR suggest normocapnia as targeted after return of spontaneous circulation [3]. This recommendation is based on heterogeneous data. While a recent meta-analysis found adverse outcome in both hyper- and hypocapnia [4], a randomized trial reported no difference in survival in low normal and high normal $\mathrm{paCO}_{2}$ [5].

The aim of the present study was to correlate arterial $\mathrm{paCO}_{2}$ and $\mathrm{pH}$ with hospital survival in eCPR.

A single-center retrospective register analysis was performed. All eCPR patients treated between 2010 and 2017 were included. We analyzed arterial blood gases after $1 \mathrm{~h}, 3 \mathrm{~h}, 6 \mathrm{~h}, 12 \mathrm{~h}$, and $24 \mathrm{~h}$ as well as hospital mortality. We detected a total of 186 eCPR. The mean age was $58.6 \pm 14.9$ years, and total hospital survival rate was $26.3 \%$. After cannulation, $\mathrm{paCO}_{2}$ and $\mathrm{pH}$ values were (mean \pm standard deviation) $38.3 \pm 8.9$ $\mathrm{mmHg} / 7.28 \pm 0.14 \quad(+1 \mathrm{~h}), \quad 38.5 \pm 8.5 \mathrm{mmHg} / 7.30 \pm 0.11$ $(+3 \mathrm{~h}), \quad 38.72 \pm 7.42 \mathrm{mmHg} / 7.31 \pm 0.11 \quad(+6 \mathrm{~h}), \quad 38.62 \pm$ $7.26 \mathrm{mmHg} / 7.34 \pm 0.10(+12 \mathrm{~h})$, and $38.22 \pm 5.62 \mathrm{mmHg} /$ $7.38 \pm 0.09(+24 \mathrm{~h}), \quad$ respectively. When comparing patients with $\mathrm{paCO}_{2}<35,35-45$, and $>45 \mathrm{mmHg}$, survival was statistically similar for all observed time points. There was however a highly significant association between hospital survival and $\mathrm{pH}$ when comparing groups with $\mathrm{pH}<7.3,7.3-7.4$, and $>7.4$ (see Fig. 1).

As secondary endpoint and surrogate for neurological outcome, neuron-specific enolase (NSE) was analyzed. Maximum NSE measured within $72 \mathrm{~h}$ after eCPR was $150.8 \pm 145.1 \mu \mathrm{g} / \mathrm{l}$ (mean \pm standard deviation). When correlating maximum NSE with $\mathrm{paCO}_{2}$ at $1,3,6,12$, and $24 \mathrm{~h}$ after eCPR, no statistical significant linear correlation was found ( $p>0.4$ for all time points). There was however a significant linear correlation of maximum NSE and $\mathrm{pH}$ at 1,3 , and $6 \mathrm{~h}$ after eCPR ( $p=0.037,0.029$, and 0.018 , respectively).

In this registry study, we found a strong correlation between hospital survival and arterial $\mathrm{pH}$ but no such

\footnotetext{
* Correspondence: xavier.bemtgen@uniklinik-freiburg.de

${ }^{1}$ Department of Cardiology and Angiology I, Heart Center Freiburg

University, Hugstetter Straße 55, Freiburg 79106, Germany

Full list of author information is available at the end of the article
} 

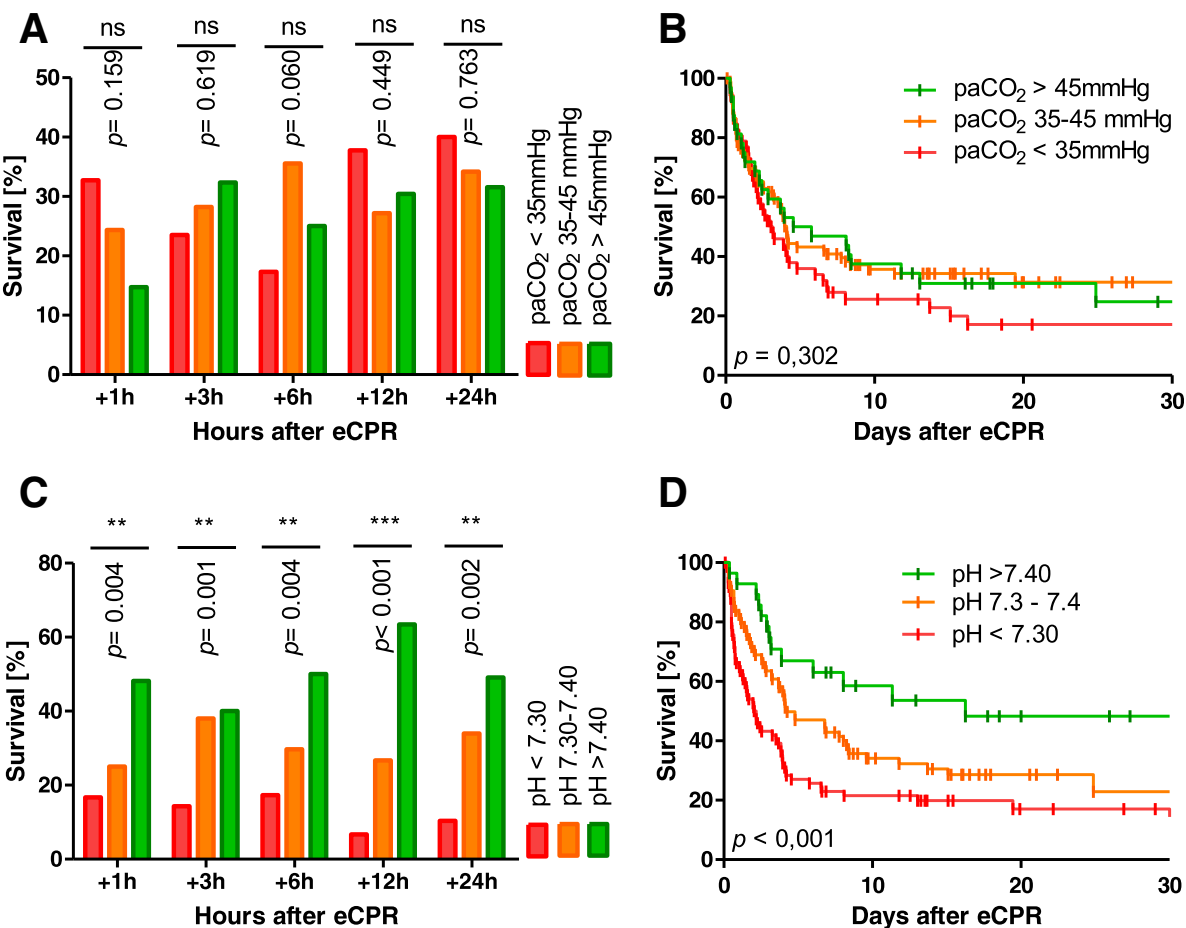

D

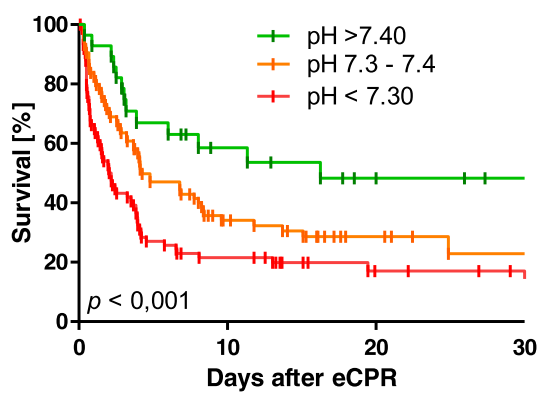

Fig. 1 Survival of eCPR patients according to $\mathrm{pH}$ and $\mathrm{paCO}_{2}$ values at different time points. No significant correlation of survival and $\mathrm{paCO}$ level $\mathrm{could} \mathrm{be}$ detected at any analyzed time point whereas $\mathrm{pH}$ was highly correlated with survival (a, $\mathbf{c}$, chi-square shown in graph). $\mathbf{b}$, $\mathbf{d}$ Example Kaplan-Meier survival curves according to $\mathrm{paCO}_{2}$ and $\mathrm{pH} 6 \mathrm{~h}$ after eCPR (log-rank tests shown in graph)

correlation with $\mathrm{paCO}_{2}$. Also elevated NSE as a marker for neural injury did correlate with $\mathrm{pH}$ but not with $\mathrm{paCO}_{2}$. Being a retrospective, observational, single-center study, inherent limitations and biases are to be presumed and findings are to be considered hypothesis generating. Until further data are available however, it might be reasonable to correct both respiratory and metabolic acidosis in eCPR patients.

\section{Abbreviations}

eCPR: Extracorporeal cardiopulmonary resuscitation; NSE: Neuron-specific enolase; $\mathrm{paCO}_{2}$ : Partial pressure of carbon dioxide in arterial blood; vaECMO: Venoarterial extracorporeal membrane oxygenation

\section{Acknowledgements}

Not applicable.

\section{Funding}

This research did not receive any specific grant from funding agencies in the public, commercial, or not-for-profit sectors.

\section{Availability of data and materials}

The datasets used and analyzed during the current study are available from the corresponding author on reasonable request.

\section{Authors' contributions}

$F S, D S$, and XB carried out the data collection, design, and planning of this study. XB and DS performed the statistical analysis and drafted the manuscript. All authors participated in the critical discussion of the study and interpretation of data. All authors read and approved the final manuscript.
Ethics approval and consent to participate

This retrospective study was approved by the ethics committee of the University of Freiburg, Germany (525/17).

\section{Consent for publication}

Not applicable.

\section{Competing interests}

The authors declare that they have no competing interests.

\section{Publisher's Note}

Springer Nature remains neutral with regard to jurisdictional claims in published maps and institutional affiliations.

\section{Author details}

${ }^{1}$ Department of Cardiology and Angiology I, Heart Center Freiburg University, Hugstetter Straße 55, Freiburg 79106, Germany. ${ }^{2}$ Department of Cardiovascular Surgery, Heart Center Freiburg University, Hugstetter Straße 55, Freiburg 79106, Germany.

Received: 19 February 2019 Accepted: 29 April 2019

Published online: 21 May 2019

\section{References}

1. Le Guen M, Nicolas-Robin A, Carreira S, Raux M, Leprince P, Riou B, et al. Extracorporeal life support following out-of-hospital refractory cardiac arrest. Crit Care. 2011;15:R29.

2. Debaty G, Babaz V, Durand M, Gaide-Chevronnay L, Fournel E, Blancher M, et al. Prognostic factors for extracorporeal cardiopulmonary resuscitation recipients following out-of-hospital refractory cardiac arrest. A systematic review and meta-analysis. Resuscitation. 2017;112:1-10.

3. Callaway CW, Donnino MW, Fink EL, Geocadin RG, Golan E, Kern KB, et al. Part 8: post-cardiac arrest care. Circulation. 2015;132:S465-82. 
4. McKenzie N, Williams TA, Tohira H, Ho KM, Finn J. A systematic review and meta-analysis of the association between arterial carbon dioxide tension and outcomes after cardiac arrest. Resuscitation. 2017;111:116-26.

5. Jakkula P, Reinikainen M, Hästbacka J, Loisa P, Tiainen M, Pettilä V, et al. Targeting two different levels of both arterial carbon dioxide and arterial oxygen after cardiac arrest and resuscitation: a randomised pilot trial. Intensive Care Med. 2018;44:2112-21.

Ready to submit your research? Choose BMC and benefit from:

- fast, convenient online submission

- thorough peer review by experienced researchers in your field

- rapid publication on acceptance

- support for research data, including large and complex data types

- gold Open Access which fosters wider collaboration and increased citations

- maximum visibility for your research: over $100 \mathrm{M}$ website views per year

At $\mathrm{BMC}$, research is always in progress.

Learn more biomedcentral.com/submissions 